\title{
A Conceptual Model of Smart Supply Chain for Managing Rice Industry
}

\author{
${ }^{1}$ TOMY PERDANA, ${ }^{2}$ YUANITA HANDAYATI, ${ }^{3}$ AGRIANI HERMITA SADELI, \\ ${ }^{4}$ DHANAN SARWO UTOMO, ${ }^{5}$ FERNIANDA RAHAYU HERMIATIN \\ ${ }^{1,3}$ Department of Agro Socio-Economics, Faculty of Agriculture, Universitas Padjadjaran, Indonesia, \\ ${ }^{2}$ School of Business and Management, Institut Teknologi Bandung, Indonesia, \\ ${ }^{4}$ Center for Sustainable Road Freight, Heriot-Watt University, Edinburgh, The United Kingdom, \\ ${ }^{5}$ Agricultural Logistics and Supply Chain (AGRILOGICS), Faculty of Agriculture, Unpad, Indonesia \\ correspondence author: ${ }^{1}$ tomy.perdana@unpad.ac.id;
}

\begin{abstract}
This research proposes a conceptual model of a smart supply chain for the rice industry. While the smart supply chain concept has started to establish in the manufacturing sector, its development and application in the agricultural sector are lacking. This research employs Soft System Methodology combined with the Value CoCreation approach to guide focus group discussion and elicit root problems and ideas from real actors in Indramayu District. The proposed conceptual model takes into account actors starting from the upstream to the downstream of the rice supply chain. Since it is developed based on real situations, it is highly relevant for supporting the local policymakers to address problems, such as lack of integration, unclear division of role, and lack of competitiveness within this supply chain. Applications beyond this case study might be beneficial for maintaining national food security.
\end{abstract}

Keywords: rice industry, value co-creation, soft system methodology

\section{Introduction}

As the Indonesian population increases, the demand for rice is also increasing. However, the competitiveness of the Indonesian rice industry remains low when compared to other ASEAN countries due to higher domestic prices relative to the imported parity rice price. Besides, the rice industry is seen as having unique characteristics and is different from the manufacturing sector. In Indonesia, high production prices have reduced incentives for farmers to maintain the sustainability of the national rice industry (Arifin, 2004; Ali, 2009). Additionally, the Indonesian government has set the Highest Retail Price (HET) for premium and medium rice. The implication of this regulation is the increasingly marginalized income and production costs released by the actors along the rice industry supply chain.

Increasing competitiveness in the rice industry is a complex and dynamic and comprises problems from the upstream to the downstream (Perdana et al., 2019; Saifullah, 2014; Perdana et al., 2016). These problems include problems in the production system, distribution, and marketing, which have not been resolved until now. Issues in these problems such as climate change, land availability, production center that are scattered in many regions. Low levels of education of upstream actors (especially farmers), lack of management of agricultural businesses, lack of openness of information flow, limited access to get the appropriate agroinput, inefficient and ineffective production techniques, improper use of machinery that causes enormous losses during the harvest and post-harvest processes related to the era of Food Losses and Waste (FLW), and unintegrated relation between supply chain actors (Hodges et al., 2010; Mulyani and Sarwani, 2013; Handayati et al., 2015).

The limitations or obstacles faced by

Received: 2019-12-17, Revised: 2020-02-05, Accepted: 2020-06-10. 
the rice industry actors have resulted in the inability of the actors to develop and improve the competitiveness and marketing of the national rice industry. They have decreased the young generation's interest in working in the rice industry (Insani et al., 2018;). The problems indirectly encourage the rice industry to increase competitiveness through cost efficiency. Thus, the rice production activities are adjusted based on the development of the needs and desires of consumers, as well as the integration between the actors involved in it (Perdana et al., 2019). The development of integration between actors along the rice industry supply chain requires an inclusive approach and active participation of all stakeholders.

Lambert and Cooper (2000) define supply chain management as integration in running business processes by involving multiple actors to provide products based on consumers' needs. It aims to tackle problems such as overproduction, stock out, to the delivery process, which may be hampered both due to internal and external factors of the company. These problems also occur in agricultural sectors such as the rice industry. According to the purpose of this study, supply chain management literature have proposed a variety of logistics development strategies by paying attention to the right production system, at the right time, at the right place at the right price for the right conditions and the right market (Mentzer et al., 2001; Buurman, 2002). One of the latest advances in the supply chain management literature is the application of a smart supply chain (Wu et al., 2016).

Just like other supply chain management concepts (Shukla and Jharkhasria, 2013), the adoption of smart supply chain concepts is, until nowadays, more common in the manufacturing sector (Wu et al., 2016). The study is adopting an intelligent supply chain in the agricultural industry, such as the rice industry, in our case study, which might be more complicated. The use of big data, the Internet of Things (IoT), cloud computing, nanotechnology, sensors, mobile computing, and various other technological innovations are beneficial to assist the rice production process. However, the adoption of these technologies requires the actors to integrate production, post-harvest, and marketing activities (Opara, 2004). Researchers have identified six elements that should be considered when applying smart supply chain concept in agriculture such as the rice industry, namely; climate and weather control (Verhagen et al., 2013; Lipper et al., 2014; Long et al., 2016; McCarthy et al., 2018), future internet and big data (Verdouw et al., 2013; Lehman et al., 2012; Tongke, 2013; Zhao et al., 2010; Channe et al., 2015; Patil and Kale, 2016; Wolfert et al., 2017), nanotechnology (Sekhon, 2014; Lu and Bowles, 2013; Scrinis and Lyons, 2007), supply chain and logistics (Verdouw et al., 2013; Reardon and Zilberman, 2018), aquaculture and water availability (Grogan, 2012; Georgakopoulos and Jayaraman, 2016) and energy (Shekhar et al., 2017).

The purpose of this research is to develop an alternative model of the smart supply chain for the rice industry. By combining Value Co-Creation and Soft System Methodology, we will take into account a broad spectrum with a range of components involved within this supply chain's activities. The model aims to solve the problems faced by upstream and downstream actors, to improve competitiveness, to strengthen integration, and impact on the sustainability of the rice industry.

The rest of our paper is organized as follows: in section two, we discuss the methodology employed in our research, continue with results and discussion that explain the supply chain mapping, value creation, and soft system methodology implementation in the rice industry. The conclusion is presented to highlight the result of the paper that answers the problems.

\section{Research Methodology}

The research takes place at the Indramayu district in West Java Province. Indramayu is appropriate as a sample for generating the smart supply chain in the rice industry as it is one of the biggest rice supply chains in Indonesia and the most productive areas in West Java. Indramayu District contributes $12.66 \%$ to the total paddy fields in West Java Province, with total grain production reaching 1.39 tons or equivalent to 799,674 tons of rice (Statistics of Jawa Barat, 2019). As many as $29.48 \%$ of Indramayu District residents make a living in the agricultural sector. However, ironically, $89.33 \%$ of the farming community in the Indramayu District live below the poverty line. This research might help to increase the regional potential through improvement in the competitiveness and sustainability of the rice 
supply chain, and this is done by involving the rice industry (such as farmers and rice mills), government, private (market), and academics.

This research combines the Value CoCreation (VCC) and Soft System Methodology (SSM) approach to have holistic perspectives and to be able to derive a conceptual model of the smart supply chain in the rice industry. Three critical stages are employed in this research (Figure 1 ). The first stage is rice supply chain mapping; the second stage is the VCC process; the third stage is SSM implementation. Moreover, in gathering data and information in each step, a purposive sampling technique was used by selecting the primary stakeholders and key informants. They have firsthand insight into the real world situation. Observation and focus group discussions (FGD) were conducted by involving farmers group, intermediaries, rice milling unit, retailer, and government.

The first stage of this research identifies the rice industry characteristics, main actors, role of each actor, cultural information, and community characteristics in Indramayu. The data and information were gathered by conducting a 1-month observation and interviewing all actors involved in the rice supply chain in Indramayu. The second stage determines the VCC process and shared value perceived by identifying the general notion of strength, weakness, challenges, and ideas in the upstream and downstream of the supply chain. In this second stage, FGD conducted involving 40 actors with different roles in the rice supply chain. VCC employs dialogue and group discussion as part of the Participatory Action Research (PAR) method. The PAR method requires the researchers and principals to identify situations, problems, and actions to change a situation in a better direction (Kusnandar et al., 2019; Kindon et al., 2007). In the VCC dialogue process, the interaction between researchers and participants must focus on developing relationships among actors so that they can develop ideas based on actions by learning from the collaborative process (Handayati et al., 2015). The third stage applies the Soft System Methodology (SSM) approach. SSM used to provide a detailed description of the processes that occur in the rice industry. The results of the visualization are then detailed again through CATWOE (Customer, Actor, Transformation, World Views, Organization, and Environment) analysis to obtain root definition problems and develop conceptual models of the rice industry's smart supply chain in Indramayu District.

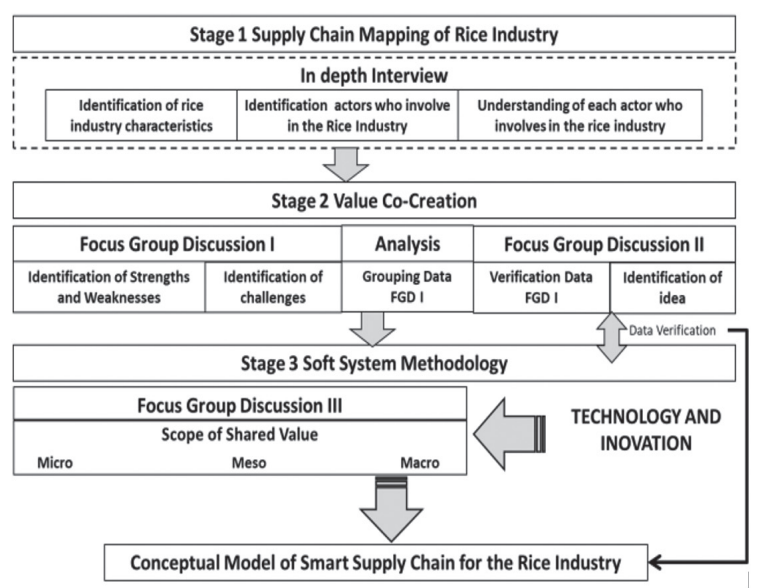

Figure 1. The Process of Developing Smart Supply Chain in the Rice Industry through a Value Co-Creation Approach

\section{Results and Discussion}

\section{Supply chain mapping of the rice industry}

The target actors identified in this study include farmers, rice processing industry, market participants, and the government. The identification of the supply chain of the rice industry is carried out by survey techniques ranging from downstream actors, namely traders, suppliers (or better known as intermediaries), the rice industry (Rice Milling Unit both small and large scale), and urban logistics service providers. Upstream rice industry actors include farmers group and farmer associations (known as Gapoktan), and farmers. The final stage is mapping out various stakeholders such as local and central government, and related associations.

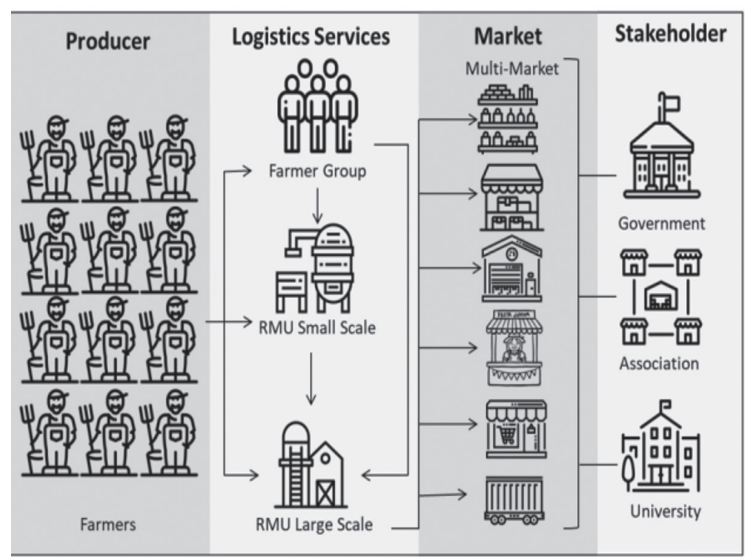

Figure 2. Supply Chain Mapping of Rice Industry in Indramayu District 
Figure 2 illustrates the rice supply chain in Indramayu District, West Java Province, which involves multiple actors. The supply chain of the rice industry includes various actors who have their respective roles with the aim of obtaining added-value products or distributing the product to the consumers. In general, farmers have more than one market partner, such as intermediaries, farmer groups, or farmer associations, as well as other rural logistics service providers (smallor large-scale Rice Milling Unit /RMU).

Thus, the products produced by farmers do not lead to just one market but can spread to traditional markets, modern markets (supermarkets/cafes/restaurants/hotels/ catering), and other manufacturing industries that are outside the producing area.

Rural logistics service providers act as actors who add value to agricultural products before the products distributed to the market. The rural logistics services in the rice industry (i.e., small-scale farmer and milling groups) provide grain into broken skin, and large-scale RMU provides rice for consumption. Largescale RMUs provide excellent rice marketing services to meet the needs of the region and outside the production area. The large-scale milling becomes a determining gate for the distribution of rice from Indramayu District to various markets in Indonesia.

The mechanism performed by the rice industry does not implement an integrated system. Therefore, the production process that occurs in the rice industry produces food losses and waste (these may happen due to overproduction, stock out, rejection, losses during the production process, transportation until the post-harvest process, and waste of the use of labor).

In line with the statement of Kader (2002), Basavaraja et al. (2007), Murthy et al. (2009), Oliveira et al. (2014), Hsiang (2010), Cederberg and Mattsson (2000), Hatfield et al. (2011), Xu et al. (2006), Gibbs et al. (2009), the process of agricultural production is very susceptible to yield loss either due to physical, chemical or biological damage by various causes during the production process.

The mapping of the rice industry supply chain is the foundation for extracting ideas and concepts from farmers as the main actors in the rice industry supply chain, farmer groups or Gapoktan as well as logistics service providers in the rice industry, market actors such as traders or suppliers, the rice industry associations and both local and central government.

\section{Value Co-Creation}

Focus Group Discussions (FGD) conducted in the value co-creation process: exploring the weaknesses and strengths of each actor, followed by exploring the challenges faced by each actor and exploring ideas and solutions together for each problem. The results of these FGDs visualized using a rich picture presented in Figure 3.

Figure 3 shows the eight foremost predicaments in the rice supply chain in Indramayu District. First, farmer regeneration is increasingly difficult. Since currently, the agricultural sector perceived to be an unpromising source of income for the young farmers. The perception that farming is a physically intensive work that dwelled in rural areas and does not guarantee welfare compared to other professions makes the youthful generation reluctant to engage in the rice industry.

Second, the provision of appropriate technology does not match the supply of frequently challenging workforce. Third, the low of seeds or superior seeds availability, as well as other agro-inputs, becomes an obstacle for farmers to produce high-grade quality products at a reasonable cost. Fourth is the further implication of the third factor, which is a decreasing level of productivity further, varying adaptability that affected by climate change, and efficient usage of agro input.

Fifth, agricultural logistics systems have not implemented in an integrated, massive, and optimal way; consequently, agricultural activities are still in a mock map. Agriculture logistics has a significant impact on the quality and continuity of product supply; in the case study area, the logistics are not well organized. Sixth, the information does not flow in both directions; hence, it impacts the capacity of farmers to align the rice production to satisfy the consumers' needs. Indirectly affects product competitiveness and food losses and waste.

Seventh, the level of education and age of farmers, most of whom are no longer in a productive period, become barriers in adopting the novel technology. Therefore, the business process managed by these farmers is still far from reaching the efficiency in rice 


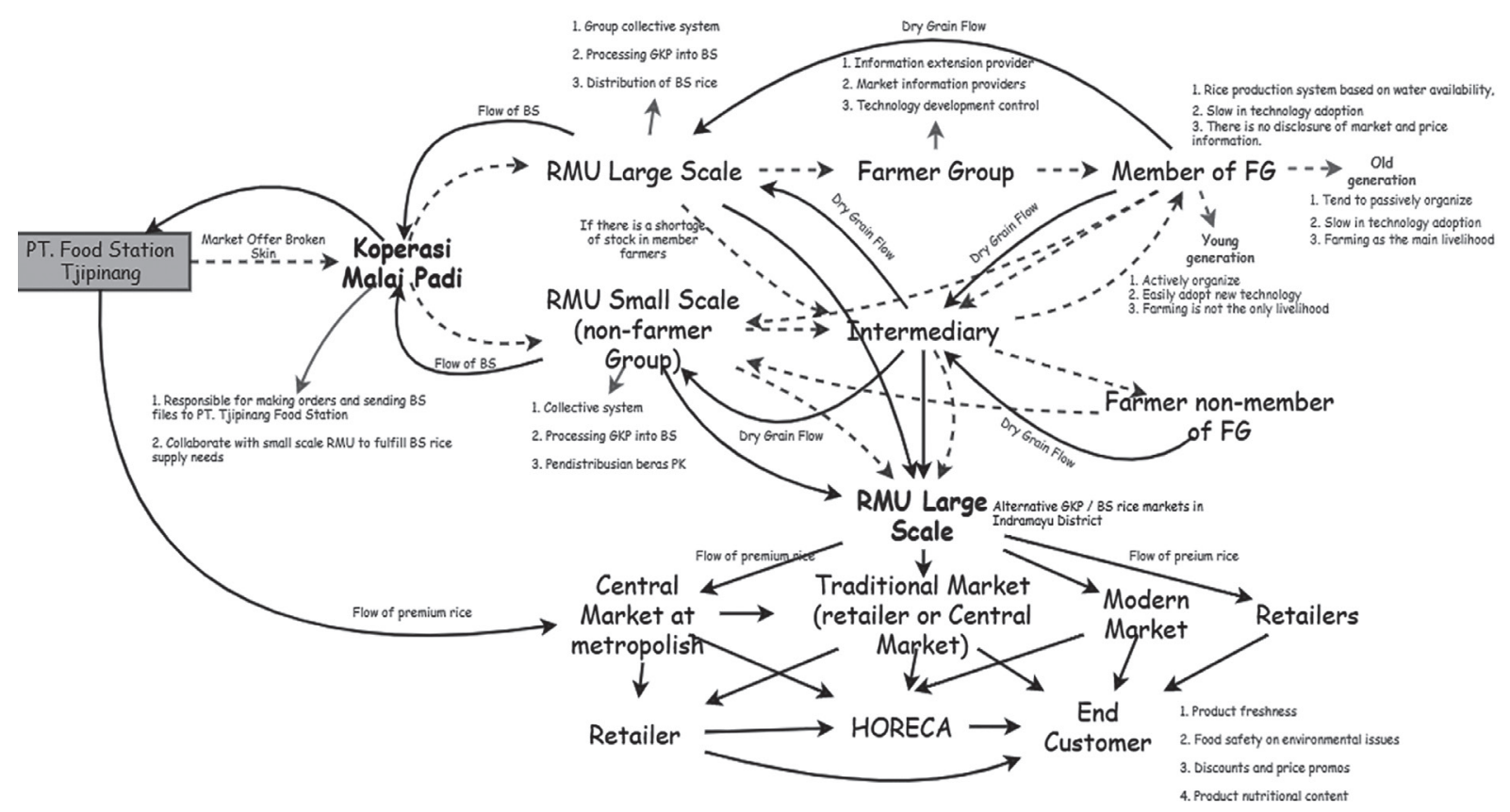

Figure 3. Rich Picture of Rice Industry in Indramayu District

production. Lastly, government regulations do not fit well with the actual conditions of the rice supply chain. The problems of local government regulation involve the mismatch between the grants aid and substantive needs, which results in an ineffective government program.

Figure 3 provides the answer to the root causes of the problems within the rice supply chain in Indramayu. Figure 3 also describes the characteristics of the rice industry, the key actors, the role of actors, and the network of actors throughout the supply chain, starting from the farmer, cooperation, food station, distributor until the end customer.

\section{Soft System Methodology}

Soft system methodology explains CATWOE analysis to describe complex situations into related and relevant categories to generate the root definition in the rice industry and define the root definition of the rice supply chain in Indramayu. In CATWOE analysis (Table 1), the structure of thinking in the rich picture is simplified into elements that are focused on the tasks and functions of each component.

The next stage is to perform a root definition analysis, which is an information system development derived from the results of the CATWOE analysis. Root definition used to simplify the problem into a format that is more detailed and relevant to the problem situation. The root definition in this research is organized into four parts, namely network, monitoring, communication, and education, as listed in Table 2.

\section{The Conceptual Model of Smart Sup- ply Chain in the Rice Industry}

After approving the root definition of the rice industry, all participants who attended the third focus group discussion agreed to categorize the building blocks of the smart supply chain in the rice industry into six components. The building blocks are: First, the area of basis production of rice commodities should be mapped in detail and aligned with market demand and supply. This alignment could be carried out by developing rice industry clusters and come up with comparative and competitive advantages. It is also noteworthy that the development of the rice industry cluster could promote the capacity building of farmers in adopting new technologies and integrating production processes and business processes connected with market players. Second, a service system needed to be built to enhance and sustain the competitiveness, product value, and capability of rice industry players, such as the development of agro-clusters, food hubs, and logistics systems to support the availability and continuity of the rice supply chain. Third, governance is an essential aspect of 
Table 1

CATWOE Rice Industry in Indramayu District

\begin{tabular}{|c|c|c|}
\hline No & Category & Rice Industry System in Indramayu District \\
\hline 1 & $\begin{array}{l}\text { Customer (beneficiaries or } \\
\text { consequences of the system or } \\
\text { transformation process) }\end{array}$ & $\begin{array}{l}\text { Farmers' cooperative (Koperasi Malai Padi), small scale RMU, } \\
\text { farmer group }\end{array}$ \\
\hline 2 & $\begin{array}{l}\text { Actor (entity or person carrying } \\
\text { out the transformation process) }\end{array}$ & Farmers, Intermediary \\
\hline 3 & $\begin{array}{l}\text { Transformation (conversion } \\
\text { from input to output) }\end{array}$ & $\begin{array}{l}\text { The need for specific criteria of rice in term of quality and } \\
\text { quantity which means it requires an open market information } \\
\text { system } \\
\text { Increasing the quality and amount of products which will } \\
\text { expect a production system with the adoption of technology } \\
\text { and linkages to market need }\end{array}$ \\
\hline 4 & $\begin{array}{l}\text { Weltanschauung/World View } \\
\text { (a perspective that makes } \\
\text { transformation meaningful) }\end{array}$ & $\begin{array}{l}\text { Market portfolios provide opportunities for small-scale RMU in } \\
\text { developing markets. Therefore, the marketing system requires } \\
\text { a market information system that is open and structured } \\
\text { through contract farming and increasing production capacity } \\
\text { for farmers so that they can meet market demands. }\end{array}$ \\
\hline 5 & $\begin{array}{l}\text { Owner (responsible person } \\
\text { or group who can stop the } \\
\text { transformation) }\end{array}$ & $\begin{array}{l}\text { Rice industry outside Indramayu District, PT. Food Station } \\
\text { Tjipinang Jaya or product user market, climate or natural } \\
\text { disasters, water availability, Government, farmers }\end{array}$ \\
\hline 6 & $\begin{array}{l}\text { Environment (environment } \\
\text { outside the given system) }\end{array}$ & $\begin{array}{l}\text { Farmers' motivation for market changes, and adoption of low } \\
\text { technology, inefficient marketing systems, smallholder groups } \\
\text { (RMU on a small scale) have limited GKP purchase capital. }\end{array}$ \\
\hline
\end{tabular}

Table 2

Root Definition in the Rice Industry in Indramayu District

\begin{tabular}{|c|c|c|}
\hline No & Category & Root Definition \\
\hline 1 & Network & $\begin{array}{l}\text { Development of a professionally managed agricultural logistics system to } \\
\text { bridge the needs of development in rural areas (production sites) with the } \\
\text { speed of market development in urban areas (urban logistics) } \\
\text { Identifying key farmers as agents of change in adopting technology for } \\
\text { farmers, especially the older farmers, }\end{array}$ \\
\hline 2 & Communication & $\begin{array}{l}\text { Integrating and coordinating the upstream and downstream actors in the } \\
\text { rice industry } \\
\text { Transparent information management that can be accessed by all actors, } \\
\text { Development of information access to farmers, } \\
\text { Establish an effective communication system }\end{array}$ \\
\hline 3 & Monitoring & $\begin{array}{l}\text { Monitoring farmer production performance } \\
\text { Establish product quality criteria based on consumer needs } \\
\text { Determine the priority challenges that need to be done related to the } \\
\text { adoption of technology and improving market networks } \\
\text { Assess and adjust logistics services based on market needs and } \\
\text { characteristics and can be implemented by upstream actors } \\
\text { Development of a food logistics service system }\end{array}$ \\
\hline 4 & Education & $\begin{array}{l}\text { Developing an agricultural training information network, technology access, } \\
\text { and market access } \\
\text { Development of an agricultural culture towards smart farming systems } \\
\text { Develop collaboration between government, private sector and universities } \\
\text { to conduct research and development of the rice supply chain network }\end{array}$ \\
\hline
\end{tabular}

developing the smart supply chain of the rice industry, notably concerning local institutional governance and suitable rules. The institution became the initial establishment in promoting the integration of the rice industry's smart supply chain model. Therefore, the integration process expected to minimize the risks that might occur in the rice industry institutions. Besides, institutional governance functions to classify the actors into their respective 
roles. The division of tasks is to illuminate the purpose of each actor in developing the rice industry. Thus, the improvement of the rice industry can be executed in a measurable and well-organized manner to achieve common goals. Fourth, the marketing of agricultural products which includes quality and continuity, traceability systems, food security, continuity of supply and prices that are relatively affordable for consumers and the right price for producers, as well as increasing national rice competitiveness. The fifth is e-commerce as an effort to face the 4.0 industrial revolution while creating value and integrating the needs of consumers. The sixth is the infrastructure that supports the implementation and development of the smart supply chain of the rice industry, which includes soft and hard technology to assist the smart supply chain development activities.

Based on the six components of the smart supply chain in the rice industry, We proposed a model of the smart supply chain for the rice industry that involves three levels that should exist and operate in an integrated manner, as illustrated in Figure 4. The components divided into micro, meso, and macro-level. The micro-level comprises of social engineering and smart technology. Meanwhile, the mesolevel consists of food hubs and agro-clusters. And the last is the macro-level consists of government policies, innovation ecosystem, rural infrastructures, and essential services. All three levels interrelated with each other; however, it should work in an integrated and sustainable way.

In the micro-level, social engineering in the agricultural and industrial supply chain smart model aims to reorganize the social structure of the community in the desired direction, based on the ability considered to understand the problem correctly to implement the solution appropriately (Fein, 2001). Also, smart technology arises because of the encouragement of market participants. Therefore, producers should develop products based on the needs and desires of consumers with the help of technology development. These intelligent technologies include the Internet of Things (IoT), sensors, devices, machines and information technology, cloud technology, and other technologies needed by farmers.

Food hubs, as a part of meso-level, are the place to conduct concentrated activities and as a business management point. The food hubs are actively administered with an aggregated management scope, with a production and marketing system to increase competitiveness and value of products that are adjusted based on the needs and desires of consumers (Barham et al., 2012). The function of the food hubs is as a logistics service provider, marketing, increasing the added value of agricultural products, providing advisory services for producers in rural areas, and acting as a web of practices for all actors. It is involved in the rice industry to support the development of agri-food practices (Berti and Mulligan, 2016).

At the same level with food hubs, agro clusters in the smart supply chain model are designed based on geographical concentrations that are interconnected and build value networks to face market challenges and opportunities (Porter, 1998; Nogales, 2010). Agro-clusters play a role as a cornerstone for involving small farmers in the rice industry where the involvement of small farmers is a characteristic of Indonesian agriculture.

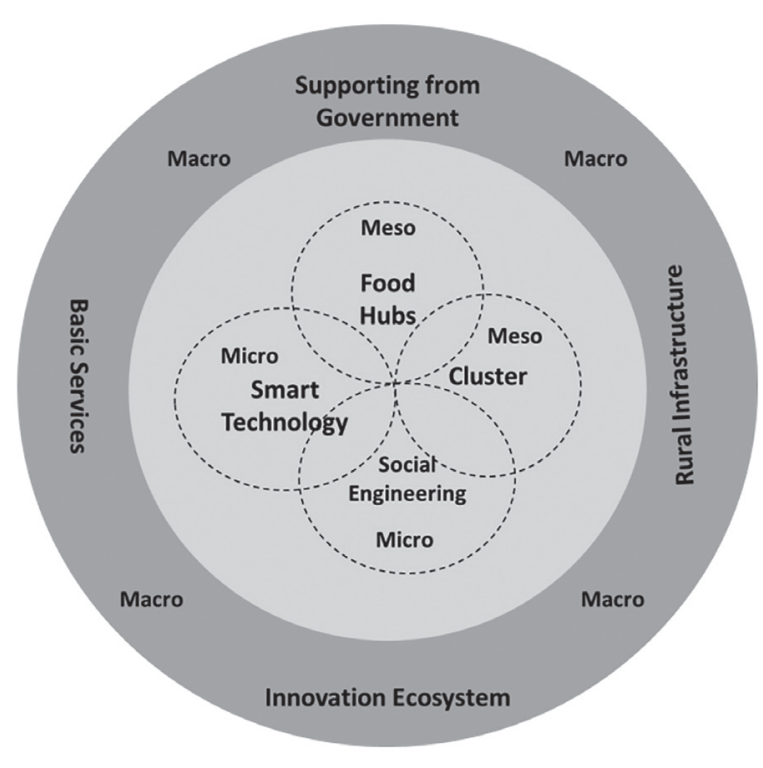

Figure 4. The Rice Industry Smart Supply Chain Conceptual Model

In the macro level, policy support from the government is vital as a form of developing synergies in utilizing potentials, reducing trade offs, and optimizing the natural resources and ecosystem services involved. Rural infrastructure is regarding developing physical infrastructure to support the sustainability of rural economic processes and non-physical infrastructure, such as the development of a rural community to obtain 


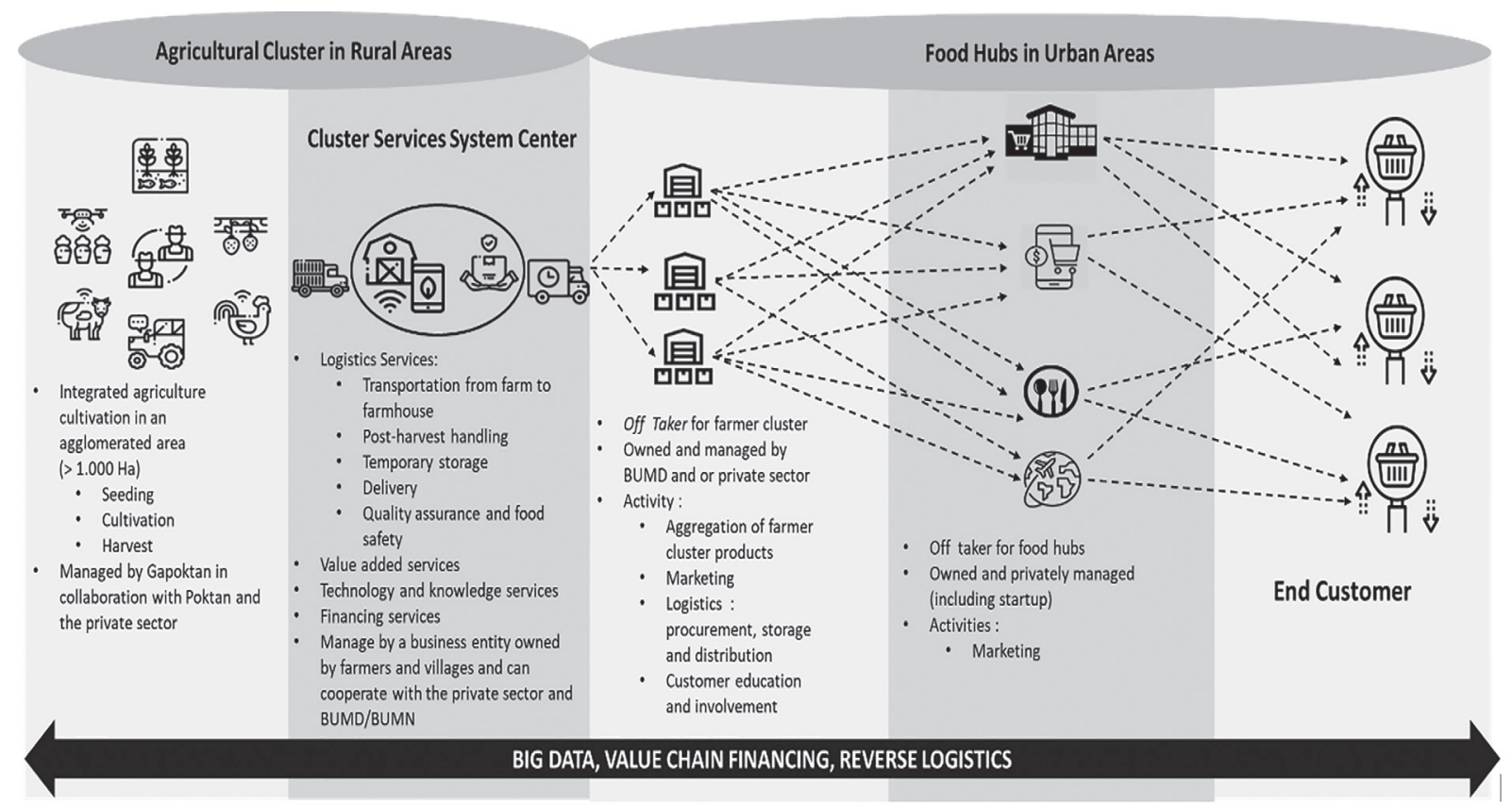

Figure 5. Logistics System in the Rice Industry Smart Supply Chain Model

intellectual and social abilities that can carry out agricultural activities.

At the same level with government policies, innovation ecosystems consist of policies and regulations, financial accessibility, knowledgeable human resources, supporting markets, energy, transportation and communication infrastructure, as well as cultures. The essential services are concerns about market information, information, and education for agriculture, information and education for pest and disease control, knowledge regarding farm management, market services, transportation, minimum essential services, including educational infrastructure and physical and spiritual health services. Further, this research also analyzed the rice industry smart supply chain model from the logistics system perspective, which accomplished the conceptual model in figure 4.

Figure 5 is a completed visualization of the smart supply chain implementation model in the rice industry obtained based on the results of discussions with the key actors. The development of a smart supply chain model for the rice industry began with developing a food hub in urban areas. The purpose of developing a food hub is to understand rice specifications based on the wants and needs of consumers, provide logistical facilities, and build openness to access information. Furthermore, the development of farmer clusters could be carried out by involving small scale farmers to produce rice based on market demand.

The development of farmer clusters could facilitate farmers in increasing product competitiveness based on market needs, thus ease farmers to understand the technological requirements needed for product development and the development of information access. The existence of food hubs and farm clusters facilitates the government and universities to develop various programs and policies related to increasing the competitiveness of the rice industry. All components should be carried out in an integrated and systematic way to achieve the common goal of increasing the competitiveness of the rice industry.

\section{Conclusions}

This research attempted to develop a model of the smart supply chain in the rice industry. The model proposed to answer the difficulties faced by upstream and downstream actors, improving competitiveness, strengthen integration, and impact on the sustainability rice industry in the future through the Value Co-Creation approach using Soft System Methodology. In developing the conceptual model of the smart supply chain for the rice industry, several elements identified, such as smart technology, social engineering, farmer clusters, and the potential of each 
base production and marketing area, are the foundation for developing the smart supply chain.

The smart supply chain model in the rice industry starts with generating a shared understanding of market needs for rice commodities through the development of food hubs. Food hubs provide a variety of urban logistics services and integrated with agricultural logistics systems managed by farmer clusters. The farm cluster acts as a forum for farmers and food hubs in providing supplies, helping farmers to improve quality, and ensuring continuity of supply based on market needs. Social engineering is an essential component in the development of systems and governance at the food hubs and farm clusters.

The next step is to initiate a variety of supporting technologies that could assist the improvement of production systems such as the development of smart technology, socio engineering, and supporting technology that tailored to the needs and development of consumers for rice consumption. The four components require support from the government in the form of policy development, necessary service development, infrastructure development, and innovation ecosystem that encourages the improvement of the competitiveness of the rice industry.

The findings were limited to delve into the root causes in the supply chain of the rice industry. Future research could take into account to find out the root causes in another supply chain of vital but problematic commodities. Also, the real-world implementation of our conceptual model, for instance, the application of food hubs in Indramayu District, particularly or Indonesia, is another potential future research. Another recommendation in the model, such as smart technology, socio engineering, and farmer clusters, also could be implemented in various ways. The quantitative approach can be employed to find out whether the proposed model significantly improves the key actors' performance and encourages sustainability.

\section{Acknowledgment}

This research was made possible by a grant from Universitas Padjadjaran and Ministry of Research, Technology, and Higher Education the Republic of Indonesia through Higher Education Applied Research (PTUPT) program as the organizer of a research activity entitled Creating Shared Value in Improving Competitiveness and Sustainability of the Rice Industry Supply Chain System in 2019-2021.

\section{References}

Ali, M., (2009). "Pendidikan untuk pembangunan nasional: menuju bangsa Indonesia yang mandiri dan berdaya saing tinggi", Jakarta: Grasindo.

Arifin, B., (2004). "Analisis ekonomi pertanian Indonesia", Jakarta: Kompas.

Basavaraja, H., Mahajanashetti, S.B. and Udagatti, N.C., (2007). Economic analysis of post-harvest losses in food grains in India: a case study of Karnataka. Agricultural Economics Research Review, 20(3472016-16622), p.117.

Barham, J., Tropp, D., Enterline, K., Farbman, J., Fisk, J. and Kiraly, S., (2012). Regional food hub resource guide (No. -2016-1470 120654).

Berti, G. and Mulligan, C., (2016). Competitiveness of small farms and innovative food supply chains: The role of food hubs in creating sustainable regional and local food systems. Sustainability, Vol. 8, No. 7, p.616.

Buurman, J., (2002). "Supply chain logistics management." McGraw-Hill.

Cederberg, C. and Mattsson, B., (2000). Life cycle assessment of milk production-a comparison of conventional and organic farming. Journal of Cleaner Production, Vol. 8, No. 1, pp.49-60.

Statistics of Jawa Barat. (2019). Kabupaten Indramayu dalam Angka 2019.

Channe, H., Kothari, S. and Kadam, D., (2015). Multidisciplinary model for smart agriculture using internet-ofthings (IoT), sensors, cloud-computing, mobile-computing \& big-data analysis. International Journal Computer Technology and Applications, Vol. 6, No. 3, pp.374-382.

Fein, M.L. (2001). Social Engineering in Context: Some Observations on Turner. Sociological Practice: A Journal of Clinical and Applied Sociology, Vol.3, pp.121-125.

Georgakopoulos, D. and Jayaraman, P.P., (2016). Internet of things: from internet-scale sensing to smart services. Computing, Vol. 98, No. 10, pp.1041-1058.

Gibbs, K.E., Mackey, R.L. and Currie, D.J., (2009). Human land use, agriculture, pesticides, and losses of imperiled 
species. Diversity and Distributions, Vol. 15, No. 2, pp.242-253.

Grogan, A., (2012). Smart farming. Engineering and Technology, Vol. 7, No. 6, pp.38-40.

Handayati, Y., Simatupang, T.M. and Perdana, T., (2015). Agri-food supply chain coordination: the state-of-theart and recent developments. Logistics Research, Vol. 8, No. 1, pp.5.

Handayati, Y., Simatupang, T.M. and Perdana, T., (2015). Value co-creation in agri-chains network: an Agent-Based Simulation. Procedia Manufacturing, Vol. 4, pp.419-428.

Hatfield, J.L., Boote, K.J., Kimball, B.A., Ziska, L.H., Izaurralde, R.C., Ort, D., Thomson, A.M. and Wolfe, D., (2011). Climate impacts on agriculture: implications for crop production. Agronomy Journal, Vol. 103, No. 2, pp.351-370.

Hodges, R.J., Buzby, J.C. and Bennett, B., (2011). Postharvest losses and waste in developed and less developed countries: opportunities to improve resource use. The Journal of Agricultural Science, Vol. 149, No. 1 , pp.37-45.

Hsiang, S.M., (2010). Temperatures and cyclones strongly associated with economic production in the Caribbean and Central America. Proceedings of the National Academy of Sciences, Vol. 107, No. 35, pp.15367-15372.

Insani, fitrah rahmah, iwan setiawan, and siska rasiska. (2018). Determinan Partisipasi Dan Peran Petani Muda Dalam Pengembangan Pertanian Ramah Lingkungan di Desa Cisondari, Kecamatan Ciwidey, Kabupaten Bandung, Jawa Barat. Mimbar Agribisnis: Jurnal Pemikiran Masyarakat IImiah Berwawasan Agribisnis Vol. 4, No. 2, pp. 153-168.

Kader, A.A., (2002). "Postharvest technology of horticultural crops (Vol. 3311)." University of California Agriculture and Natural Resources.

Kindon, S., Pain, R. and Kesby, M. eds., (2007). "Participatory action research approaches and methods: Connecting people, participation and place", Routledge.

Kusnandar, K., van Kooten, O. and Brazier, F.M., (2019). Empowering through reflection: participatory design of change in agricultural chains in Indonesia by local stakeholders. Cogent Food and Agriculture, Vol. 5, No. 1, p.1608685.

Lambert, D.M. and Cooper, M.C., (2000). Issues in supply chain management. Industrial marketing management, Vol. 29, No. 1 , pp.65-83.
Lehman, B., D'Mello, S. and Graesser, A., (2012). Confusion and complex learning during interactions with computer learning environments. The Internet and Higher Education, Vol. 15, No. 3, pp.184-194.

Lipper, L., Thornton, P., Campbell, B.M., Baedeker, T., Braimoh, A., Bwalya, M., Caron, P., Cattaneo, A., Garrity, D., Henry, K. and Hottle, R., (2014). Climate-smart agriculture for food security. Nature Climate Change, Vol. 4, No. 12, p.1068.

Lu, J. and Bowles, M., (2013). How will nanotechnology affect agricultural supply chains?. International Food and Agribusiness Management Review, Vol. 16

Long, T.B., Blok, V. and Coninx, I., (2016). Barriers to the adoption and diffusion of technological innovations for climatesmart agriculture in Europe: evidence from the Netherlands, France, Switzerland and Italy. Journal of Cleaner Production, Vol. 112, pp.9-21.

McCarthy, N., Lipper, L., \& Zilberman, D. (2018). Economics of climate smart agriculture: An overview. In Climate Smart Agriculture (pp. 47-31). Springer, Cham.

Mentzer, J.T., DeWitt, W., Keebler, J.S., Min, S., Nix, N.W., Smith, C.D. and Zacharia, Z.G., (2001). Defining supply chain management. Journal of Business logistics, Vol. 22, No. 2 pp.1-25.

Mulyani, A. and Sarwani, M., (2013). Karakteristik dan potensi lahan sub optimal untuk pengembangan pertanian di Indonesia. Jurnal Sumberdaya Lahan, Vol. 7, No. 1.

Murthy, D.S., Gajanana, T.M., Sudha, M. and Dakshinamoorthy, V., (2009). Marketing and post-harvest losses in fruits: its implications on availability and economy. Indian Journal of Agricultural Economics, Vol. 64

Nogales, Eva Galvez. (2010). "Agro Based Clusters in Developing Countries: Staying Competitive in A Globalized Economy", Rome, FAO.

Oliveira, C.M., Auad, A.M., Mendes, S.M. and Frizzas, M.R., (2014). Crop losses and the economic impact of insect pests on Brazilian agriculture. Crop Protection, Vol. 56, pp.50-54.

Opara, L., (2004). Emerging technological innovation triad for smart agriculture in the 21st century. Part I. Prospects and impacts of nanotechnology in agriculture. International Commission of Agricultural Engineering

Patil, K.A. and Kale, N.R., (2016). A model 
for smart agriculture using IoT. In 2016 International Conference on Global Trends in Signal Processing, Information Computing and Communication (ICGTSPICC) (pp. 543-545). IEEE.

Perdana, T., Sadeli, A.H., Hermiatin, F.R. \& Ginanjar, T., (2019), October. Lean management in the rice industry; case study at Widasari, Indramayu district. In IOP Conference Series: Earth and Environmental Science (Vol. 335, No. 1, p. 012024). IOP Publishing.

Perdana, T., Heriyanto, M.A., Kurnia, G., Kuswaryan, S., Fitriani, L.K. \& Sanjaya, S., (2016), October. Sustainable Agribusiness Cluster Development. In Green Development International Conference (GDIC 2016) (p. 27).

Porter, M. E. (1998). Clusters and the new economics of competition (Vol. 76, No. 6, pp. 90-77). Boston: Harvard Business Review.

Reardon, T. and Zilberman, D., (2018). Climate smart food supply chains in developing countries in an era of rapid dual change in agrifood systems and the climate. In Climate Smart Agriculture (pp. 351-335). Springer, Cham.

Saifullah, A., (2014). Tantangan Perberasan Nasional Menghadapi Pasar Tunggal ASEAN 2015 National Rice Challenges Facing the ASEAN Single Market in 2015. JURNAL PANGAN, 23(2), pp.178-193.

Scrinis, G. and Lyons, K., (2007). The emerging nano-corporate paradigm: nanotechnology and the transformation of nature, food and agri-food systems. International Journal of Sociology of Food and Agriculture, 15(2), pp.22-44.

Sekhon, B.S., (2014). Nanotechnology in agri-food production: an overview. Nanotechnology, science and applications, Vol. 7, p.31

Shukla, M. and Jharkharia, S., (2013). Agri-fresh produce supply chain management: a state-of-the-art literature review. International Journal of Operations and Production Management, Vol. 33, No. 2, pp.114-158.

Shekhar, S., Colletti, J., Muñoz-Arriola, F., Ramaswamy, L., Krintz, C., Varshney, L., \& Richardson, D. (2017). Intelligent infrastructure for smart agriculture: An integrated food, energy and water system. arXiv preprint arXiv:1705.01993.

Tongke, F., (2013). Smart agriculture based on cloud computing and IOT. Journal of Convergence Information Technology, Vol. 8, No. 2.

Verhagen, S. and Teunissen, P.J., (2013). The ratio test for future GNSS ambiguity resolution. GPS solutions, Vol. 17, No. 4, pp.535-548.

Verdouw, C.N., Beulens, A.J.M. and Van Der Vorst, J.G.A.J., (2013). Virtualisation of floricultural supply chains: A review from an Internet of Things perspective. Computers and electronics in agriculture, Vol. 99, pp.160-175.

Wolfert, S., Ge, L., Verdouw, C. and Bogaardt, M.J., (2017). Big data in smart farming-a review. Agricultural Systems, Vol. 153, pp.69-80.

Wu, L., Yue, X., Jin, A. and Yen, D.C., (2016). Smart supply chain management: a review and implications for future research. The International Journal of Logistics Management. Vol. 27, pp.395-417

Xu, H., Ding, H., Li, M., Qiang, S., Guo, J., Han, Z., Huang, Z., Sun, H., He, S., Wu, H. and Wan, F., (2006). The distribution and economic losses of alien species invasion to China. Biological Invasions, Vol. 8, No. 7, pp.1495-1500.

Zhao, J.C., Zhang, J.F., Feng, Y. and Guo, J.X., (2010). The study and application of the IOT technology in agriculture. In 2010 3rd International Conference on Computer Science and Information Technology, Vol. 2, pp. 462-465. IEEE. 